\title{
Improving Students' Reading Comprehension by Using Think Pair Share (TPS) at Grade VIII SMP N 9 Padangsidimpuan
}

\author{
By: Eka Sustri Harida, M.Pd., Fitri Rayani Siregar, M.Hum., \\ and Ismail Zuhri
}

\begin{abstract}
ABSTRAK
Penelitian ini dilakukan untuk memecahkan masalah siswa dalam pemahaman bacaan. Penelitian ini bertujuan untuk mendeskripsikan peningkatan pemahaman bacaan siswa dengan menggunakan Think Pair Share dan mengidentifikasi faktor-faktor yang mempengaruhi peningkatan pemahaman bacaan siswa dengan menggunakan Think Pair Share di kelas VIII SMP N 9 Padangsidimpuan. Berkaitan dengan tujuan penelitian, desain penelitian yang digunakan dalam penelitian ini adalah penelitian tindakan. Ada 24 siswa sebagai peserta dan juga berkolaborasi dengan guru bahasa Inggris. Data dikumpulkan dengan menggunakan teknik observasi catatan, wawancara, dan tes (siklus uji 1 dan siklus uji 2). Peneliti menganalisa mean skor siswa dan menggunakan t-test untuk mengetahui signifikansi peningkatan pemahaman bacaan siswa. Temuan penelitian menunjukkan bahwa penggunaan TPS dapat meningkatkan pemahaman bacaan siswa termasuk siswa mampu: (1) mengidentifikasi gagasan utama teks; (2) mengidentifikasi informasi spesifik dari teks; (3) mengidentifikasi kosakata teks; (4) mengidentifikasi referensi teks; dan (5) mengidentifikasi pernyataan yang benar atau salah. Selain itu, peningkatan pemahaman bacaan siswa dapat dilihat dari peningkatan skor rata-rata tes baca pada siklus I yaitu sebesar 63,95 (25\%) dan tes baca pada siklus II sebesar 81,45 (79,16\%). Berdasarkan catatan observasi, situasi kelas juga membaik. Perbaikan situasi kelas meliputi: Sebagian besar siswa aktif dan komunikatif selama proses belajar mengajar dan siswa mulai lebih antusias dalam membaca kelas.
\end{abstract}

\section{Keywords: Kemampuan Membaca \& Tekhnik Think Pair Share}

\section{A. Background of the Study}

Teaching reading in SMP N 9 Padangsidimpuan is based on the SchoolBased Curriculum. ${ }^{1}$ The School Based Curriculum is an operational curriculum that is arranged, developed, and implemented by each school that is ready and able to develop it. School Based Curriculum consists of the target education of level based

${ }^{1}$ Private Interview, Teacher of Grade VIII SMP N 9 Padangsidimpuan, (Hutaimbaru: October 
education, structure and contents of the curriculum in the educational unit level, educational calendar and syllabus. The development of School Based Curriculum is taken references on Content Standard (Standar Isi) and Graduate Competence Standard (Standar Kompetensi Lulusan). In the area of teaching reading for junior high school, the students are expected to be able to understand written text to reach the functional level including the ability of understanding many kinds of short functional texts, procedure texts, descriptive texts, recount texts, narrative texts and report texts. ${ }^{2}$ It means that teaching and learning process in English, students need to have good reading skill in order to comprehend those material well.

There must be a suitable technique or method for teaching reading in which students can explore their idea to improve their reading comprehension. One of the strategies that can be applied is Think Pair Share. Think Pair Share can be said effective to use in teaching learning process, especially in reading comprehension. It is strengthened by Anita Lie states that Think Pair Share can be applied to all subject and grade levels. ${ }^{3}$

The proves that think pair share technique is effective to be used can be seen from the previous research. Actually, there were some researchers had done experimental research about the effect of think pair share on students' reading comprehension. The first is journal written by Arini Ayuning Palupi. ${ }^{4}$ The result of the research showed there was a significant difference of the students' reading comprehension achievement after being taught through Think-Pair-Share (TPS). Furthermore, experimental research conducted by Al Furqon. ${ }^{5}$ The findings of this study showed that there was significant difference in reading comprehension achievement between the students who were taught by using Think Pair Share and those who were taught by using Teacher-Centred method. So, the researcher need to prove further by conducting a classroom action research (CAR).

\footnotetext{
${ }^{2}$ BSNP, Standar Isi dan Standar Kompetensi Kelulusan untuk Satuan Pendidikan Menengah SMP/MTs/SMPLB, (Jakarta: Dharma Bakti, 2006).

${ }^{3}$ Lie, A, Cooperative Learning: Mempraktikan Cooperative Learning di Ruang - Ruang Kelas. (Jakarta: Grasindo, 2002), p. 57.

${ }^{4}$ Arini Ayuning Palupi, Ujang Suparman \& Ramlan Ginting Suka, Teaching Reading Comprehension Through Think-Pair Share (TPS) Technique, accessed from http://jurnal.fkip.unila.ac.id/index.php/123/article/view/1180/741, retrieved 20 April 2017 at 09.50 a.m

5 Al Furqon, The Effect of Think-Pair-Share Model and Motivation on Students' Reading Comprehension Achievement, accessed from http://ejournal.unsri. ac.id/index.php/jenglish/article/ view/2212/1030 retrieved 20 April 2017 at 09.55 a.m
} 
In conclusion, this technique will help teacher to create a learning environment which engages individual achievement and group achievement. Lie stated that Think-Pair-Share (TPS) techniques provide an opportunity for students to work both individually and in groups ${ }^{6}$. This strategy is expected to be able to motivate the students to achieve and be actively involved in the teaching and learning of reading. So, researcher is interested to use Think Pair Share in this research because many advantages of Think Pair Share that can be used in reading comprehension.

\section{B. Purposes of the Research}

Based on the formulations of the problem above, the purposes of this research are:

1. To describe the improvement of students' reading comprehension by using Think Pair Share at grade VIII SMP N 9 Padangsidimpuan.

2. To identify the factors that influence the improving students' reading comprehension by using Think Pair Share at grade VIII SMP N 9 Padangsidimpuan.

\section{Indicator of Action}

Action research in education is any systematic inquiry conducted by teachers, principals, school counsellors, or other stakeholders in the teaching learning environment that involves gathering information about the ways in which their particular schools operate, the teachers teach, and the students learn. ${ }^{7}$ It means that Classroom Action Research aims to improve the process and learning outcomes in classes conducted in cyclical. CAR is action research which is done at classroom by teacher to improve learning practice quality. The problem of CAR must be started from teacher who wants to improve the quality of education. Based on the research problem, the researcher uses CAR because the researcher wants to know all of the process which must be done as teacher to student to develop

\footnotetext{
${ }^{6}$ Lie, A, Cooperative Learning: Mempraktikan Cooperative Learning di Ruang - Ruang Kelas. (Jakarta: Grasindo, 2002), p. 57.

${ }^{7}$ L. R. Gay \& Peter Airasian, Education Research: Competence for Analysis and Application, (USA: Prentice Hall, Inc, 2012), p. 509.
} 
students' reading comprehension in narrative text. There are steps of doing in classroom action such as planning, action, observation, and reflection.

During the implementation of the actions, Researcher would make the program, lesson plan, and apply that will use think pair share in the classroom. Moreover, the researcher would collaborate with English teacher to become a teamwork who works together for solving the students' problem in improving reading comprehension at Grade VIII SMP N 9 Padangsidimpuan. So, the indicators of action in reading comprehension in narrative text by using think pair share technique are: identifying main idea, specific information, textual reference, vocabulary and true or false statement.

Moreover, researcher would give test to find out reading comprehension of the students to read narrative text by using think pair share technique at grade VIII SMP N 9 Padangsidimpuan. In addition, the researcher also would give observation notes, and interview to support this research.

\section{Theoretical Review of Terminologies}

\section{The Description of Reading Comprehension}

Reading comprehension is a complex process which comprises the successful or unsuccessful use of many abilities. The reader should be able to recall information afterwards. Klinger describe that reading comprehension is a multicomponent, highly complex process that involves many interactions between readers and what they bring to the text (previous knowledge, strategy use) as well as variables related to the text itself (interest in text, understanding of text types). ${ }^{8}$ Ministry of Education Ontario states reading comprehension the process of making sense of text - is a complex, multifaceted activity that calls on the reader's thinking and problem-solving skills. ${ }^{9}$ So, the readers have to reconstruct the author's message. If the readers can read the words of a text, but get nothing about what they are reading, they are not really reading.

From the statement above, it can be concluded that reading comprehension is active process in which readers try to construct meanings by

${ }^{8}$ Klinger,J.K, Vaughn.S, \& Boardman A, Teaching Reading Comprehension to Students with Learning Difficulties, e-book, (New York: The Guilford Press,2007) p. 8.

${ }_{9}^{9}$ Ministry of Education, A Guide To Effective Instruction In Reading: Kindergarten To Grade 3, e-book, (Ontario:Queens' Printer, 2003), p. 83. 
using any information from a text, evaluate the information, and then compare the information with their background knowledge.

\section{a. Principle of Teaching Reading}

Principles of teaching reading are the principles that the teacher should pay attention in teaching learning process of reading. In this case, the researcher describes six principles purposed by Harmer. The six principles are as follow ${ }^{10}$ :

1) Reading is not a passive skill,

2) Students need to be engaged with what they are reading,

3) Students should be encouraged to respond to the content of a reading

4) Text, not just to the language,

5) Prediction is a major factor in reading,

6) Match the task to the topic,

7) Good teachers exploit reading texts to the full.

Those are principles of teaching reading comprehension which must be regarded as the teacher's principle in teaching reading. Those principles are used as the direction for the teacher. The teacher should know what the students need to learn and not. The teacher must know the main of teaching reading and what the teaching reading should be.

From the explanations above, it can be concluded that the teacher should understand what is reading itself and should be careful in deciding the teaching method, the text, the material, and the activity when he/she designs the lesson. Therefore, the purpose of improving students' reading comprehension can be achieved.

\section{The Description of Narrative Text}

\section{a. Definition of Narrative Text}

Narrative is one of the most commonly read, though least understood of all the genres. Narrative is a form of text that is used to tell or relate the story of acts or events, some usually tells about person, place, animal and thing. The story can be fiction, non-fiction, or a combination of both.

${ }^{10}$ Jeremy Harmer, The Practice of English Language Teaching, e-book, (Edinburgh: Pearson Education Limited, 2001), p. 70. 
Narrative text is character-oriented, commonly written based on life experience and built using descriptive familiar language and dialogue.

Reading narrative text is different from reading other kinds of texts. Narrative text is a collection of written words that seeks to entertain, display knowledge or skill, teach, organize, and plan behaviours, most frequently involving imaginative stories with a setting, character, and plot. According to John Langan, in narration, writer tells the story of something that happened. ${ }^{11}$ It means that narration is done by somebody in the past time.

In general, narrative text is organized into the beginning, the middle and the end. To build this story grammar, narrative text needs a plot, a series of episodes which hold the readers' attention while they are reading the story. The plot will determine the quality of the story, with conflict being its main, important element. The conflicts among the characters will drive the story's progress, in which the readers will be shown how the characters face the problem and how they have the ability to handle that problem and come into a resolution.

Based on the explanation above, researcher concludes that narrative text is text tells about the past time which contents is about a story, fable, fairy tales, folk tale, legend, or short which consist of generic structure, orientation, complication, and resolution.

\section{b. Purpose of Narrative Text}

The purpose of narrative text is mainly to entertain, to tell story, or to provide an aesthetic experience. It supported by Sanggam Siahaan and Kisno Shinoda, they said that narration is any written English text in which the writer wants to amuse, entertain people, and to deal with actual or vicarious experience in different way. ${ }^{12}$

The essential purpose of narrative is to tell a story, but the detailed purpose may vary according to genre. For example, the purpose of a myth is often to explain a natural phenomenon and a legend is often intended to pass

11 John Langan, Collage Writing Skills with Readings, (New York: McGraw-Hill Book Company,2003), p. 111. p. 73.

${ }^{12}$ Sanggam Siahaan \& Kisno Shinoda, General Text Structure, (Yogyakarta: Graha Ilmu,2008), 
on cultural traditions or beliefs. ${ }^{13}$ Reader can take the social function on the narrative text such as attitude and opinion. Some narrative texts will create the way to solve the problem.

\section{c. Generic Structure of Narrative Text}

In general, narrative text is organized into the beginning, the middle and the end. To build this story grammar, narrative text needs a plot, a series of episodes which hold the reader 's attention while they are reading the story. The plot will determine the quality of the story, with conflict being its main, important element. The conflicts among the characters will drive the story 's progress, in which the readers will be shown how the characters face the problem and how they have the ability to handle that problem and come into a resolution.

According to Mark and Kathy Anderson, narrative text provides the elements of narrative text; they are consisting of orientation, complication, sequence event, resolution and coda. ${ }^{14}$ To make it clear, it will be explained as below:

1) Orientation

This is the part in which the narrator tells the audience about who is in the story, when the story is taking place and where the action is happening. So, it can be called as introduction the part of the story. The reader can figure out what will happen next and who are included.

2) Complication

The part of the story where the narrator tells about something that will begin a chain of the event. These events will affect one or more of character. So, this part is talking about the totally playing of character.

\footnotetext{
${ }^{13}$ Crown, 2013, A Guide to Text Types: Narrative, Non-fiction and Poetry, accessed from http://www.literacytrust.org.uk/assets/0001/6612/Guide_to_text_types_Sample.pdf retrieved on April 10th, 2017 at 11.30 am

${ }^{14}$ Mark Anderson \& Kathy Anderson, Text Types in English 2, (South Yarra: Mcmillan, 2003), p. 12.
} 
3) Sequence event

Narrator tells some events in the story.

4) Resolution

This part can be found in the last story. Here, the complication will be solved.

5) Coda

Provides a comment or moral based on what has been learned from the story.

\section{d. Language Features in Narrative Text}

There are some language features in narrative text. It contained in narrative text. ${ }^{15}$ They can be used as the characteristics to identify narrative in the text. It can be below:

1) Past tense (killed, drunk, etc)

2) Adverb of time (Once upun a time, one day, etc)

3) Time conjunction (when, then, suddenly, etc)

4) Specific character. The character of the story is specific, not general. (Cinderella, Snow White, Alibaba, etc)

5) Action verbs. A verb that shows an action. (killed, dug, walked, etc)

6) Direct speech. It is to make the story lively. (Snow White said,"My name is Snow White). The direct speech uses present tense.

Narrative text should have the characteristics above. It usually uses past tense in actions or the events. Then, it uses adverb of time in the story, time conjunction, specific character, and direct speech.

\section{The Description of Think Pair Share}

Anita Lie state that Think-Pair-Share can be applied to all subjects and grade levels. ${ }^{16}$ So, Think Pair Share technique has been a foundational tool in

${ }^{15}$ Adeulfayani, Narrative Text, accessed from https://adeulfayani.wordpress. com/narrative text-2/, retrieved October 02th, 2016 at 11.30 am

${ }^{16}$ Lie, A, Cooperative Learning: Mempraktikan Cooperative Learning di Ruang - Ruang Kelas. (Jakarta: Grasindo, 2002), p. 57. 
cooperative learning, it can be applied such as in many classrooms, workshops, and training rooms. Think Pair Share increase the engagement of all learners with the subject matter and provides the facilitator time to make better decision. At the same time, it can help to develop communication skill.

From the definitions above, the researcher could conclude that ThinkPair-Share gets its name from the three stages of student action, with emphasis on what students are to be doing at each of those stages. Think-Pair-Share refers to one of the cooperative learning strategy that sets students to work in pairs. Students have to think about a topic and share their idea with pairs. Therefore, they have opportunities to convey their idea and share the idea in whole class or in a group.

According to Arends, there were three steps in teaching reading using think pair share, as follows:

Step 1 Thinking: The teacher poses a question or an issue associated with the lesson and asks students to spend a minute thinking alone about the answer or the issue. Students need to be taught that talking is not part of thinking time.

Step 2 Pairing: Next, the teacher asks students to pair off and discuss what they have been thinking about. Interaction during this period can be sharing answers if a question has been posed or sharing ideas if a specific issue was identified. Usually, teacher sallow no more than four or five minutes for pairing.

Step 3 Sharing: In the final step, the teacher asks the pairs to share what they have been talking about with the whole class. It is effective to simply go around the room from pair to pair continue until about a fourth or a half of the pairs have had a chance to report. ${ }^{17}$

So, there are three steps in think pair share. The first step is THINK, the students work independently to think about a question or issue, the second step is PAIR, they pair with one of their peer to share their ideas to each other and the last step is SHARE, the students in each pair work together to share their ideas to the class.

17 Arends, R. I., Learning to Teach: 9thEdition, e-book, (New York: The McGraw Hill Companies, 2009), p. 370-371. 
Moreover, there are many advantages of Think-Pair-Share model. Kagan in journal of Dino Sugiarto and Puji Sumarsono mentions some advantages of Think-Pair-Share technique, they are:

1) When students have appropriate "think time," the quality of their responses improves.

2) Students are actively engaged in thinking.

3) Thinking becomes more focused when it is discussed with a partner.

4) More critical thinking is retained after a lesson in which students have had an opportunity to discuss and reflect on the topic.

5) Many students find it easier or safer to have a discussion with another classmate, rather than with a large group.

6) No specific materials are needed for this strategy, so it can be easily incorporated into lessons.

7) Building on the ideas of others is an important skill for students to learn. ${ }^{18}$ :

\section{E. Hypothesis of the Action}

The hypothesis of this research is stated that: "Think Pair Share Technique can improve students' reading comprehension at grade VIII SMP $\mathrm{N} \quad 9$ Padangsidimpuan”.

\section{F. Research Methodology}

\section{Location and Schedule of the Research}

The location of the research was at SMP N 9 Padangsidimpuan. It is located at Jl. Sudirman KM 4,5 Hutaimbaru, Kecamatan Padangsidimpuan Hutaimbaru. The research started from May 2016 until September 2017.

\section{Research Design}

Gay and Eurasian stated that "classroom action research is a type of practioner research that is used to improve the practioner's practice, action implies doing or changing something". ${ }^{19}$ Anne Burns describes "Classroom Action Research is part of a broad movement that has been going on education; it involves taking a self-reflective critical, and systematic approach to explore

${ }^{18}$ Dino Sugiarto \& Puji Sumarsono, The Implementation of Think-Pair-Share Model to Improve Students' Ability in Reading Narrative Texts, International Journal of English and Education ISSN: 22784012, Volume:3, Issue:3, July 2014, accessed from http://ijee.org/yahoo_site_admin/assets/docs/ 21.184151514.pdf retrieved October 03th, 2016 on 09.30 am

${ }^{19}$ L.R.Gay \& Peter Airasian, Education Research: Competence for Analysis and Application, (USA: Prentice Hall, Inc, 2009), p. 593. 
the teaching context". ${ }^{20}$ Additionally, classroom action research is different from the other types of research. It was focused on individual or small group professional practice and it was not concern with making general statement. In this research, the researcher directly involved in improving students' reading comprehension. The study was conducted collaboratively which involved the English teacher, the researcher and the students.

Classroom action research consists of four steps through planning, action, observation and reflection. This design showed the improvement of practice in the classroom that was done through cyclical action to be implemented continuously to reach what the research wanted to do at first. The main role of action research is to facilitate and to improve the learning process and learning strategies.

\section{Subjects of Research}

The subjects of this research were the students at grade VIII, the second semester in academic years 2016/2017 SMP N 9 Padangsidimpuan. There are ten classes of grade VIII in SMP N 9 Padangsidimpuan from VIII-1 until VIII10. The researcher chose VIII-2 as the subjects of this research because the researcher found some problems of reading comprehension in this class. The students consisted of 24 students.

\section{G. CONCLUSION}

Based on the result of the classroom action research had done, it could be concluded that:

1. Think Pair Share improved the students' reading comprehension in narrative text at grade VIII SMP N 9 Padangsidimpuan. It proved by increasing the mean of students' reading comprehension score from $63.95(25 \%)$ in the cycle I to $81.45(79.16 \%)$ in the cycle II.

2. There were five internal factors wich influencing the students' reading comprehension in narrative text. They were; main idea, specific information, vocabulary, textual reference and true or false statement.

${ }^{20}$ Anne Burns, Doing Action Research in English Language Teaching, (New York: Routledge, 2010), p. 2. 
Then, there were two external factors that influencing the students' reading comprehension in cycle I and cycle II such as like confidence and disturbance in the classroom. Therefore, the hypothesis in this research could be accepted because the score of the students and the students' activity in learning process by using Think Pair Share showed the good improvement at grade VIII SMP N 9 Padangsidimpuan.

\section{REFERENCES}

Adeulfayani, Narrative Text, https://adeulfayani.wordpress.com/narrativetext-2/, accessed at October 02th, 2016 retrieved on $11.30 \mathrm{am}$.

Al Furqon, The Effect of Think-Pair-Share Model and Motivation on Students' Reading Comprehension Achievement, from http://ejournal.unsri.ac.id/index.php/jenglish/article/view/2212/1030 retrieved from 20 April 2017 at 09.55 a.m

Anderson, Mark \& Kathy Anderson, Text Types in English 2, South Yarra: Mcmillan, 2003.

Arends, R.I, Learning to Teach: 9thEdition. e-book. New York: The McGraw Hill Companies,2009.

A.S. Hornby, Oxford Advanced Learner's Dictionary of Current English, New York: Oxford University Press, 1974.

Brasell, Danny, Comprehension That Work, e-book, Huntington Beach: Shell Education, 2008.

Broughton, Geoffrey, Teaching English as a Foreign Language (Second Edition), USA: Routledge, 1980.

Brown, Douglas, Principles of Language Learning and Teaching: Fourth Edition, ebook, USA, Pearson Education,2000.

Language Assessment Principles and Classroom Practices. New York: Longman, 2004.

BSNP, Standar Isi dan Standar Kompetensi Kelulusan untuk Satuan Pendidikan Menengah SMP/MTs/SMPLB, Jakarta: Dharma Bakti, 2006.

Burns, Anne, Doing Action Research in English Language Teaching, New York: Routledge, 2010. 
Caldwell, JoAnne Schudt, Reading Assessment: A Primer for Teachers and Coaches Second Edition, e-book, New York: The Guilford Press, 2008.

Cathy Allen Simon, Using the Think-Pair-Share Technique accessed from http://www.readwritethink.org/professional-development/strategy guides/usingthink-pair-share-30626.html retrieved October 04th, 2016 on $11.30 \mathrm{am}$

Creswell, John W, Research Design: Qualitative, Quantitative and Mix Method Approaches-Second Edition, USA: Sage Publication inc, 2003.

Crown, A Guide to Text Types: Narrative, Non-fiction and Poetry, 2013, accessed from http://www.literacytrust.org.uk/assets/0001/6612/Guide_to_text_types_Sample.pd $f$ retrieved April 10th, 2017 on 11.30 am

Denning, Steve, How Story Telling Ignites Action Knowledge Era Organization, 2000. accessed from http://www.stevedenning.com//maintypesstory.html retrieved October 03th, 2016 on 10.30 am

Depdiknas, Panduan Penyusunan KTSP Jenjang Pendidikan Dasar dan Menengah, Jakarta: BP Citra Jaya, 2006.

Dino Sugiarto \& Puji Sumarsono, The Implementation of Think-Pair-Share Model to Improve Students' Ability in Reading Narrative Texts, International Journal of English and Education ISSN: 2278-4012, Volume:3, Issue:3, July 2014, accessed from http://ijee.org/yahoo_site_admin/assets/docs/21.184151514.pdf retrieved October 03th, 2016 on 09.30 am

Gay, L.R. \& Peter Airasian, Education Research: Competence for Analysis and Application: sixth edition, USA: Prentice Hall, Inc, 2000.

Gede Natha Darsana, "Improving Reading Comprehension Through Think Pair Share Technique of the Tenth Grade Studentse of SMK PGRI 4 Denpasar in 2013/2014 Academic Year", accessed from http://unmas-library.ac.id/wpcontent/uploads/2014/11/IMPROVING-READING-COMPREHENSIONTHROUGH-THINK-PAIR-SHARE-TECHNIQUE-OF-TENTH-GRADESTUDENTS-OF-SM.pdf retrieved September 22th, 2017 on 11:44 a.m

Harmer, Jeremy, The Practice of English Language Teaching, e-book, Edinburgh: Pearson Education Limited, 2001.

, The Practice of English Language Teaching (Third Edition Completely Revises and Update), e-book, England: Longman, 2003.

Hartono, Statistik:Untuk Penelitian, Yogyakarta: Pustaka Pelajar Offset, 2004.

Johnson, Andrew P., Teaching Reading and Writing: A Guidebook for Tutoring and Remediating Students, e-book, USA: Rowman \& Littlefield Education, 2008.

Kagan, Spencer \& Miguel Kagan, Kagan Cooperative Learning, e-book, San Clemente: Kagan Publishing, 2009. 
Klinger, J.K, Vaughn.S, \& Boardman A, Teaching Reading Comprehension to Students with Learning Difficulties, e-book, New York: The Guilford Press,2007.

Knapp, Peter \& Megan Watkins, Genre, Text, Grammar: Technologies for Teaching and Assessing Writing, e-book, A UNSW Press book: Sydney, 2005.

Langan, John, Collage Writing Skills with Readings, New York: McGraw-Hill Book Company,2003.

Leipzig, D. H. 2001. "What is Reading? WETA", accessed from http://www.readingrockets.org/article/352, retrieved November 1th 2016 on 04:17 pm.

Lie, A, Cooperative Learning: Mempraktikan Cooperative Learning di Ruang - Ruang Kelas. Jakarta: Grasindo, 2002.

Luh Tri Jayanti Swastyastu, "Improving Reading Comprehension of The Tenth Grade Students of SMK N 5 Denpasar In Academic Year 2013/2014 By Using Numbered Heads Together", accessed from http://unmas-library.ac.id/wpcontent/uploads/2014/05/CHAPTER-NEW.pdf retrieved April 12th, 2017 on 10.35 a.m

Madsen, Harold S. Techniques in Testing, e-book, New York: Oxford University Press, 1983.

Miftahul Huda, Cooperative Learning, Yogyakarta: Pustaka Pelajar, 2012.

Ministry of Education, A Guide To Effective Instruction In Reading: Kindergarten To Grade 3, e-book, Ontario:Queens' Printer, 2003.

M. Rahmani \& K. Sadeghi, 2011, Effects of Note Taking on Reading Comprehension and Recall, International Journal of Humanities and Social Science, 11(2), 116128, http://www.ijhssnet.com accessed at Maret, 12th 2017 retrieved on 02:05 pm

Ni Kadek Listiani, “Improving Students' Reading Comprehension Through Think Pair Share at The Eight Grade Students of SMP2 Abiansemal In Academic Year 20132014", Denpasar: Maharaswati University, 2013, accessed from http://unmaslibrary.ac.id/wp-content/uploads/2014/05/THESIS.pdf, retrieved April 12th, 2017 on 10.40 a.m

Nunan, David, Practical English Language Teaching, New York: Mc.Grow-Hill Company, 2003.

Palupi, Arini Ayuning, Ujang Suparman \& Ramlan Ginting Suka, Teaching Reading Comprehension Through Think-Pair Share (TPS) Technique, accessed from http://jurnal.fkip.unila.ac.id/index.php/123/article/view/1180/741, retrieved 20 April 2017 at 09.50 a.m

Patel, M.F \& Jain, M. Praveen, English Language Teaching (Methods, Tools and technique), e-book, Jaipur: Sunrise,2008. 
Siahaan, Sanggam \& Kisno Shinoda, General Text Structure, Yogyakarta: Graha Ilmu,2008.

Situmorang, Muhammad Faisal \& Bachtiar, Improving Students' Achievement In Reading Report Text By Using Think-Pair Share Strategy, http://jurnal.unimed.ac.id/2012/index.php/eltu/article/view/1378/1137, accessed at October 23rd, 2016 retrieved on 01:17 p.m.

Sudijono, Anas, Pengantar Statistik Pendidikan, Jakarta: PT Raja Grafindo Persada, 2008.

Tarigan, Henry Guntur Membaca Sebagai Suatu Keterampilan Berbahasa, Bandung: Angkasa, 2005.

Vaughn, Sharon \& Sylvia, Linan-Thompson, Research-Based Methods of Reading Instruction, Grades K-3, e-book, Virginia USA: Association for Supervision and Curriculum Development (ASCD), 2004.

Weir, Cryril J. Communicative Language Testing, UK: Printice Hall, 1990.

Zainal Aqib et. al., PTK untuk Guru SMP, SMA, SMK, Bandung: CV. Yrama Widya, 2008. 